\title{
THE GROUP CONCEPT OF BUILDING RASO BATALUN IN THE PERFORMANCE OF TALEMPONG RENJEANG ANAM SALABUHAN
}

\author{
Andar Indra Sastra*
}

\begin{abstract}
ABSTRAK
Tulisan ini bertujuan untuk membahas talempong renjeang anam salabuhan sebagai artefak hasil kebudayaan, khususnya konsep kelompok dalam membangun raso batalun dalam penyajian talempong renjeang anam salabuhan di Luhak Nan Tigo di Minangkabau. Raso batalun dalam penyajian talempong merupakan ekspresi musikal yang diwujudkan pemain talempong dalam bentuk ekspresi penggarapan ritme talempong. Ekspresi dalam penyajian talempong dapat dimaknai sebagai kemampuan musikal kelompok penyaji talempong dalam memainkan berbagai ragam Guguah talempong. Kelompok merupakan representasi dari konsep sosial dalam masyarakat Minangkabau. Ada kelompok talempong yang dibentuk atas dasar tujuan dan kepentingan bersama tanpa adanya ikatan hubungan kekeluargaan; ada kelompok talempong yang dibentuk atas dasar hubungan kekerabatan; dan ada kelompok bermain talempong yang dibentuk berdasarkan hubungan genealogis. Kesatuan musikal dibangun melalui komunikasi musikal antar pemain talempong melalui pola ritme yang berbeda. Komunikasi musikal dapat dicapai ketika pemain dalam kelompok memiliki persepsi, kemampuan dan rasa musikal yang setara. Persepsi dan kemampuan musikal dan rasa musikal itu menjadi modal awal untuk dapat menyajikan talempong sesuai dengan standar musikal setiap kelompok. Standar musikal diyakini tidak akan dicapai ketika peran seseorang diganti dengan orang-orang yang bukan dari kelompok mereka. Peranan kelompok sangat penting dalam membangun kesatuan musikal dan standar musikal untuk mencapai raso batalun.
\end{abstract}

Kata Kunci: galuik, kelompok, komunikasi musikal, Luhak Nan Tigo Minangkabau, raso batalun, standar musikal, talempong renjeang

\begin{abstract}
The goal of this article is to discuss talempong renjeang anam salabuhan as a cultural artefact, in particular focusing on the group concept of building raso batalun in the performance of talempong renjeang anam salabuhan in Luhak Nan Tigo, Minangkabau. Raso batalun in the performance of talempong is the musical expression created by the talempong player through the rhythmic treatment of the talempong. The expression produced in a talempong performance can be understood to reflect the musical ability of the talempong group in its performance of various types of Guguah talempong. A group is the representation of a social concept in Minangkabau society. Some talempong groups are formed on the basis of common goals and interests without any family connections; other groups are formed through family ties; and others are formed based on genealogical connections. A musical unit is built through musical communication between the talempong players through different rhythmic patterns. This musical communication can be achieved when the players in the group have the same level of perception, ability, and sense of musicality. It is this perception and
\end{abstract}

* Karawitan Department, Performing Arts Faculty, Institut Seni Indonesia Padangpanjang, West Sumatra 
sense of musicality which are the initial foundations on which a talempong performance is built, in accordance with the musical standard of each group. It is believed that a high musical standard will not be reached if the role of a particular player is taken over by another player from outside the group. The group plays an important role in building a musical unit and a musical standard in order to achieve raso batalun.

Keywords: galuik, group, Luhak Nan Tigo Minangkabau, musical communication, musical standard, raso batalun, talempong renjeang

\section{INTRODUCTION}

Talempong renjeang anam salabuhan is a kind of rhythmic percussion music found in Luhak Nan Tigo, Minangkabau, consisting of six pencon or gong chimes. Sedyawati states that Luhak Nan Tigo is recognized as the homeland of the Minang tradition, and includes Luhak Tanah Data, Luhak Agam, and Luhak 50 Koto. Sjafri Sairin, Demokrasi dalam Kebudayaan Minangkabau, in Jurnal Humaniora, said states that traditionally, the Minangkabau district is divided into two parts, namely Darek and Rantau. Darek is the area located around Mount Merapi and is believed to be the original home of the Minangkabau people, and is made up of three parts, or Luhak, namely Luhak Agam, Luhak Tanah Data, and Luhak 50 Koto. The area outside the Darek area is known as the Rantau area, or the area where Minangkabau communities moved subsequently. This area is located mainly to the West and East of Luhak Nan Tigo (Sairin, 1995:87-93). Other areas of West Sumatra-now known as cities and regencies-are primary settlement areas of the Minangkabau community. Other places outside West Sumatra, to which the Minang tradition has spread, may be referred to as the "second circle of Minang culture". The original land of Minang tradition is also known as "darek"-land, as opposed to "pasisie", which literally means "a place beside the sea" (Edi Sedyawati, 2007:337). Talempong is played by three musicians, each of whom plays two talempong instruments. The talempong is held (direnjeang) in the left hand and struck (diguguah) with the right hand which holds a special kind of beater (pangguguah), creating a short melody which is typical of talempong renjeang Minangkabau. Adam states that the word "talempong" in Minangkabau refers to the instrumental classification known as the idiophone, which can be found in various shapes and sizes, and may be made from various different materials, and is played by being struck. In its most common form, the talempong is an instrument shaped like a small gong, made from a metal alloy and struck to produce a sound (Adam, 1986/1987:9-10). Talempong renjeang falls into the common description given by Adam.

From a musical point of view, talempong renjeang consists of three pairs of talempong, each pair being given various different names by the local community. This article will use one of the most common sets of names that are used in the local community, namely talempong Jantan, talempong Paningkah, and talempong Pangawinan. Pangawinan with a capital $P$ means a pair of talempong, and pangawinan with a small $p$ is a philosophical concept which is the basis of the formation of the three pairs of talempong renjeang anam salabuhan in Luhak Nan Tigo Minangkabau. From the results of an observation of the formulation of these talempong pairs, it can be understood that talempong maestros or experts (tuo) have the knowledge and musical sensitivity to identify and differentiate the order of sounds based on their musical experience as talempong maestros. Their knowledge and musical sensitivity formed the basis on which to create the talempong renjeang anam salabuhan pairs known as talempong Jantan, Paningkah, and Pangawinan. These three talempong pairs are played by three musicians who use a technique known as basaua, or interlocking patterns. This means that each player produces a rhythmic motif with his own pair of talempong instruments to 
create a talempong renjeang musical composition which is rhythmic in character, and also to develop the melodic treatment by using an improvisational technique known as galuik.

The concept of batalun has a different meaning when connected to an object than its meaning in a literal sense. In a literal sense, Sugono states that the word bertalun (Minang=batalun) comes from the root word talun, which means "resound" or "echo"; hence bertalun means to resound or to echo (Sugono 2008:1426). This concept is significantspecifically because its object exists in a performance of talempong renjeang anam salabuhan in which the performer is involved in an aesthetical situation. The aesthetical situation in a talempong performance has a profound meaning in the minds and feelings of the talempong performers (artists) and also the audience. This profound meaning deserves special attention since a talempong performance has a level of complexity in which the group has the important role of creating raso batalun. The problem to be addressed in this article, which is based on the results of a research study, is how important the role of the group is in creating raso batalun in a performance of talempong renjeang anam salabuhan in Luhak Nan Tigo Minangkabau.

The goal of this research is to compile an aesthetical model for the performance of talempong renjeang anam salabuhan based on the concept of batalun. The additional goal of this research is to correct the misunderstandings of academics in general about the art of talempong renjeang anam salabuhan. The methods used were observation and interviews with a number of informants. This study aims to uncover a concept that originates from the conscious experience of talempong renjeang anam salabuhan artists in Luhak Nan Tigo. This conscious experience forms the basis for developing knowledge and much of this knowledge is contained in the experiences of the talempong artists. Raso batalun is one of the experiences of Minang artists and also the Minang community in connection with the performance of talempong renjeang anam salabuhan.
Pairs of talempong are formed based on the concept of pangawinan through the methods dilipek duo and dipatukakan (doubled and interchanged). Lipek duo and dipatukakan are methods that are formed from the arrangement of sounds in the musical system of talempong. This system of talempong music is extended according to a mathematical progression-in a line, from the highest to the lowest pitch of talempong-T6, T5, T4, T3, T3, T2, and T1. The three talempong at the end of the series are moved to the bottom-referred to as dilipek duo. In this way, the talempong begin to appear in pairs, and the talempong in the last position-at the end of the second row-is interchanged with the talempong in the middle. The way in which the pairs of talempong are formed based on the order of the highest to the lowest pitches can be seen in the following diagram:

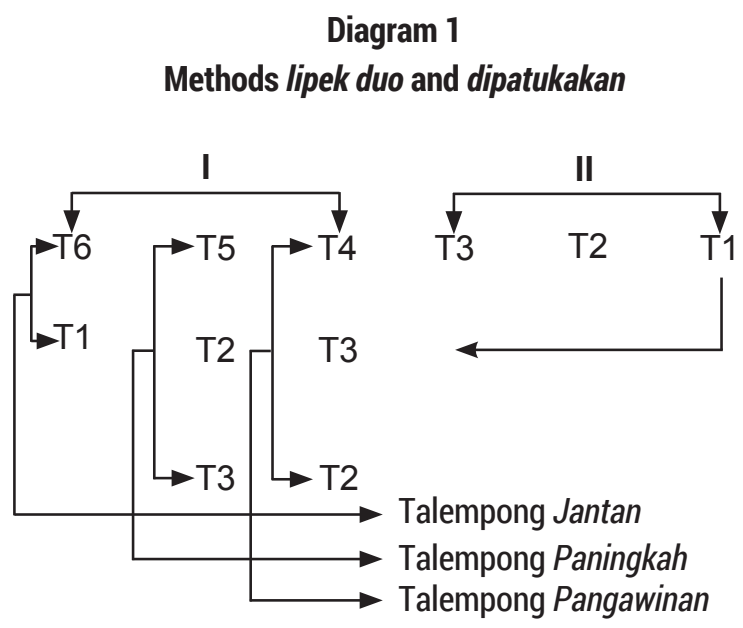

The formation of the concept of talempong pairs as shown in the diagram above has become a reference for talempong artists all over Luhak Nan Tigo Minangkabau to identify a talempong partner who is suitable and matches their own musical taste.

Musical interaction is the manifestation of the rhythmic play of the three talempong musicians in accordance with the main role, function, and authority of each pair of talempong instruments. The talempong Jantan, with its consistent beat, acts as the "leader" and directs the theme of the Guguah talempong that is being 
played. In addition, the talempong Jantan player controls the stability of the tempo, or danyuik in a performance. Musically, the talempong Paningkah, with the use of a different rhythmic pattern, responds to the rhythms played by the talempong Jantan. The combination of the rhythmic motifs of these two players forms a melodic framework to suit the theme being performed by the talempong Jantan. The talempong Pangawinan, also with a different rhythmic pattern, provides a balance and at the same time "justifies" the success of the Guguah talempong. The role of the talempong Pangawinan player is to provide variations, which in the talempong renjeang tradition are known as galuik. These characteristics are all related to the physical aspects in order to describe what is meant by raso batalun. Raso batalun is related to sound, acoustics, and physical aspects, and includes single sounds and multiple or complex sounds. Raso batalun also means the patterns of the pairs of instruments and the musical interaction of rhythmic play between the talempong Jantan, talempong Paningkah, and talempong Pangawinan. The unity between the physical aspects and the feeling, or raso, is a unity which conceptually expresses raso batalun as a phenomenon in a performance of talempong renjeang anam salabuhan which is well compiled or perfectly formed. Sutiyono said a phenomenon is something that can be experienced or felt with the senses and can be explained and evaluated in a scientific manner, such as a natural phenomenon; it is something which attracts attention or is extraordinary in nature; something that is different from everything else (Sugono, 2010:408). Phenomenology is the science which studies the process of human awareness in recognizing symptoms/phenomena that appear before people's eyes. Phenomenology produces knowledge about essence. What is meant by essence is the meanings, interpretations, significance, values, and symbols that exist in the phenomenon or symptom that is seen, whether hidden or not,and which are viewed as the substance of a qualitative explanation (Sutiyono, 2011:25-26).

\section{THE GROUP CONCEPT OF BUILDING RASO BATALUN}

Recognition of a group is the first step towards building raso batalun. If a person or talempong player does not belong to a particular group, it will be difficult to establish the level of musical communication that is necessary for creating raso batalun. It is quite probable that a person from another group will not have the same musical perception of the talempong Guguah (vocabulary) that is being played. In terms of the musical communication, the recognition of a group has a psychological effect on creating a musical feel for building raso batalun. This means that the concept of a group is highly significant in building raso batalun in a performance. This significance can be seen in a number of different aspects, such as (1) the command of Guguah and interpretation; (2) the ability to build musical communication; and (3) the variations or galuik (literally: "wrestling").

\section{Command of Guguah and Interpretation}

A good command of Guguah and interpretation is not only concerned with the musical ability of the talempong player in each different role. This musical ability is related to the player's command of a variety of rhythmic motifs in the various Guguah talempong. Musical skill must be accompanied by an equal level of skill in interpretation-raso-in the Guguah that is being performed. This interpretation, or raso, in turn must be supported by a similar level of musical ability in playing the Guguah talempong. A command of Guguah and interpretation are two of the main elements needed for building raso batalun.

The command of the Guguah and the interpretation of the Guguah will only appear in a group that is bound together by strong emotional ties. In connection with this, there are a number of conditions needed for forming a talempong renjeang group. Firstly, every member of the group must be aware that he is part of the group. Secondly, there must be a good reciprocal 
relationship between members of the group. Thirdly, there must be at least one common factor in the group, such as a common interest, or a common goal. These factors are what unite the group or establish an emotional bond. Such an emotional bond-or sensitivity to raso-can be built if the members of a group have a sense of belonging and a similar perception about the Guguah talempong that is claimed to belong to their particular group. The talempong groups that exist can be divided into three main categories, namely those with: (a) a common interest; (b) family ties; and (c) genealogical connections.

\section{Common Interests}

On the basis of common interests and goals, a group will endeavour to develop common perceptions and raso. This kind of group is formed on the basis of common interests and awareness and consists of individuals or people from different backgrounds. They may have different ages, educational backgrounds, ethnicity, musical ability, and musical raso for the talempong renjeang. These differences require a relatively lengthy rehearsal process in order to achieve an aesthetical quality and raso batalun in their performance of talempong renjeang. To Giddens, this kind of awareness is equal to what may be described as "sensibility" (Giddens, 2011:54-55). Sensibility can of course unite the raso in order to achieve an aesthetical quality in the talempong performance.

Several such groups that are built on the basis of common interests and goals have emerged in various parts of Luhak Nan Tigo Minangkabau. This kind of group is becoming well-organized in establishing its direction and its goals. It is organized in the form of smaller art groups in various areas, such as the groups Sovyani, Indojati, Mayang Taurai, and so on. This kind of group is more oriented to the aspect of professionalism in its performance. The raso batalun that is presented through talempong renjeang has undergone various aesthetical changes. This is due to a number of factors, such as the change in musical style or aesthetical value of the talempong from the traditional to a more modern concept. This modern concept means that the musical system of the talempong used is tuned according to the Western concept of diatonic tuning.

This change in orientation has caused a change in the system of values, which in turn has influenced the musical aspects, and similarly, the musical aspect affects the musical quality of the raso batalun. This means that a talempong group which was formed on the basis of common interests and goals no longer has the ability to achieve raso batalun in its performances. This is due to the change in the tuning system of the talempong which has adopted the concepts and aesthetical ideology of modern or Western music. These changes can be felt when players read the order of pitches according to the "solmisation" system that is commonly used when reading diatonic music. Making the music system in talempong diatonic has meant that slowly but surely the aesthetic feel or raso is beginning to shift towards the ideology of Western music. John Fiske states that a system of knowledge is an ideology. Ideology works within a cultural domain in such a way as to make a capitalist system appear quite natural and as though there is no other choice (Fiske, 2011:17). The use of musical instruments such as a keyboard, piano, or recorder to tune the talempong pitches means that talempong musicians are being carried away by, if not becoming a "slave" to, the ideology and way of thought of modern culture. Suka Harjana implies that we prefer to "look at and enter another person's garden to take the fruit from a plant that we did not ourselves plant" (Harjana, 2003:18). Hastanto describes a similar impression in the following way:

This is because the majority of people in this country have left behind their own tradition and believe that they have entered into a new culture which they refer to as 
modern. In fact, this is not necessarily the case. Perhaps they are entering into a modern culture yet without realizing it, they have become "culturally homeless", that is they have left behind their old home-their traditional culture-but have failed to enter a new home-the modern culture (Hastanto, 2012: 1).

Both Harjana and Hastanto emphasize the fact that a change in ideology, or taking fruit from a garden where we did not plant it, or leaving behind our traditional culture, in the case of the Minang community, means that there has also been a change in mentality which in turn can cause a change in the aesthetical feel or raso of the talempong, because members of society are beginning to leave behind their own tradition.

\section{Family Ties}

In Minangkabau, family ties include those between brothers and sisters, in-laws, and family members who are related through marriage, and include people of various ages, educational backgrounds, and of course, different levels of musicality. These groups are bound by family ties, and as such, find it relatively easier to achieve a common sense of raso in order to achieve an aesthetical quality in a talempong renjeang performance. Factors such as emotional bonds due to family ties have a significant effect on the ability to establish musical communication in a command of various Guguah talempong. This musical communication may run smoothly when the players all have a similar vision about the theme and musical feel of each Guguah talempong.

This emotional bond is built on the basis of family ties in which raso is the criterion on which considerations are based in building verbal communication between the members. By taking into consideration the aspect of raso when carrying out this verbal communication, they will more easily establish a common perception of the variety of different Guguah talempong. This does not mean that a group which is built based on family ties will automatically have the ability to master a wide range of Guguah talempong without first having to master musical techniques, in accordance with the main role, function, and authority of each pair of talempong instruments. Nevertheless, from the aspect of musical communication, a talempong performance by a group which was formed on the basis of family ties will be quicker to develop better musical communication when they are performing a variety of Guguah talempong.

\section{Genealogical Connections}

This kind of group is formed on the basis of genealogical connections or blood ties. In the Minangkabau kinship system, family ties refer to the matrilineal system. This kind of group is quicker to develop communication through nonverbal symbols. The members have the ability to respond quickly and understand one another, and also have sensitivity to raso. Groups that are formed on the basis of genealogical connections are more sensitive to raso and have the ability to respond quickly and understand what the other members mean through symbols or the body language of their family members. Their feelings, or raso, are more strongly connected than members of a group who do not have any genealogical connections. Deleuze, in his book entitled, "What is Philosophy: Reinterpretasi Atas Filsafat, Sain dan Seni", states that people with genealogical connections are in the same rhythm as one another (Giles Deleuze \& Felix Guattari, 2010:Lxi). The power of raso in the genealogical sense will be even stronger between twins. Identical twins often feel a stronger connection than non-identical twins. Therefore, a unique phenomenon sometimes occurs in which one twin has the ability to feel what the other twin is feeling. This kind of communication between twins is still surrounded by mystery. Some people say that at a young age, twins communicate exclusively by means of telepathy, and according to Kak Seto, the phenomenon of telepathy can be explained in two ways. The first explanation 
is that a twin has the extraordinary ability to read non-verbal signs of communication from the other twin. This means that they will respond more quickly to each other than anyone else around them. "Telepathy is the ability for a twin to respond very quickly to the other twin," he says. Not surprisingly, twins are highly sensitive and accurate in understanding each other's body language because they have been together almost all their lives (Kak Seto, http://www. psikomedia.com/article/vliew/Psikologi/2136/ Si-Kembar-Berkomuni-kasi-Lewat-Telepati/). The genealogical factor has a significant effect on uniting the raso in an attempt to create an aesthetical quality in a performance of talempong renjeang anam salabuhan in Luhak Nan Tigo Minangkabau.

\section{Developing Musical Communication}

The ability to develop musical communication is the second element needed to create raso batalun. Musical communication is concerned with the musical symbols that are produced through the sound of the talempong. These musical symbols adhere to the rhythmic motifs that are played by the three talempong musicians and establish musical communication, meaning that a "transaction" has taken place or the coordination of an exchange of symbols between the talempong players. Musical coordination is established when the three players respond to each other through different rhythmic motifs within the musical structure. In Capra's opinion, communication is not the transfer of information but rather the coordination of behaviour between living organisms through a mutually beneficial interaction in a structural manner (Fritjof Capra: 2002:65). This means that the coordination between the behaviour of one person and another is the basis for establishing musical communication in a talempong performance (see the picture 1).
Picture 1

A Talempong Performance by a Group that was Formed on The Basis of Family Ties. The Performance Took place at a Traditional Cow Race (Pacu Jawi) in Luhak Tanah Data

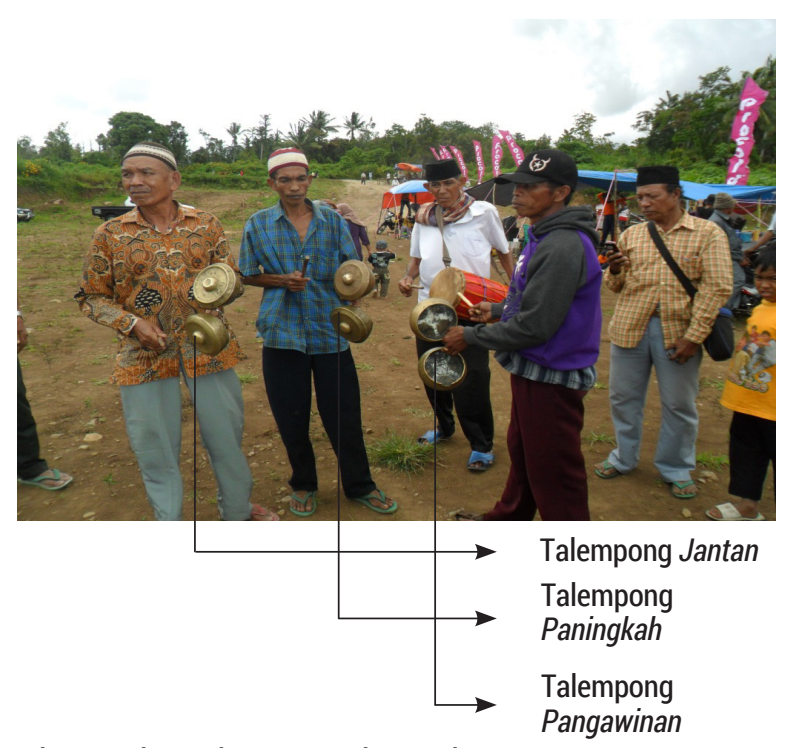

Photo: Private documentation Andar 2013

The effect of musical communication on the way of thought and behaviour is in the response that is given to the other partner in communication in the form of different musical behaviour. This musical response should be given within a musical pattern and based on a different rhythmic motif -as a form of behaviour. The nature of musical communication in a performance of talempong renjeang is to build raso batalun. The nature of musical communication is of course different from two-way verbal communication involving two communicators. In a performance of talempong renjeang, communication can be divided into two categories: (a) internal communication and (b) external communication.

\section{Internal Communication}

Internal communication is the musical communication that takes place during a performance of talempong renjeang in the form of a triangular interaction through symbols which 
respond to one another according to the motifs played by the three musicians. The rhythmic motifs of the talempong Jantan are responded to by the talempong Paningkah by playing different or contrasting rhythmic motifs. This different kind of musical communication is in turn responded to by the talempong Pangawinan which also plays different rhythmic motifs. The musical communication that takes place in the form of rhythmic interaction produces the short melodies that are characteristic of talempong renjeang anam salabuhan in Luhak Nan Tigo Minangkabau.

The three talempong pairs described above are each integral parts of the endeavour to achieve an aesthetical feel in a performance of talempong renjeang. In a performance, the feeling, or raso, is manifested in the form of three different patterns which create a single unit. Raso is present here in the different patterns, each of which plays its own complementary role. This mutually complementary role in the context of different forms can be described in terms of the traditional philosophy "basilang kayu dalam tungku, di sinan api makonyo hiduik" (the criss-cross pattern of wood in the fireplace, where the fire breathes and gives life). Criss-cross describes the opposing directions of the wood in the fireplace which provide room for the air to breathe life to the fire. The criss-cross patterns of the wood which give a chance for the fire to stay alive until the rice is boiling is an antithesis; the cooked rice is the synthesis or the final product.

This is a relationship that is built on opposing forms-air and fire have a synergic connection through the criss-cross patterns of the wood. The meaning of life in the achievement of an aesthetical quality in a talempong renjeang performance is the implementation of a difference in musical raso that is formed through the relationship between the three pairs of patterns to create a balance. Dharsono states that balance is the equilibrium between opposing or contradictory elements. In a work of art, although the different elements may seem to be contradictory, each element does in fact need the other elements because together they create a unit; with this equilibrium between opposing values, an aesthetical balance can be created (Dharsono, 2011:29). In a performance of talempong renjeang anam salabuhan, balance in aesthetical contradiction can be described in the following diagram:

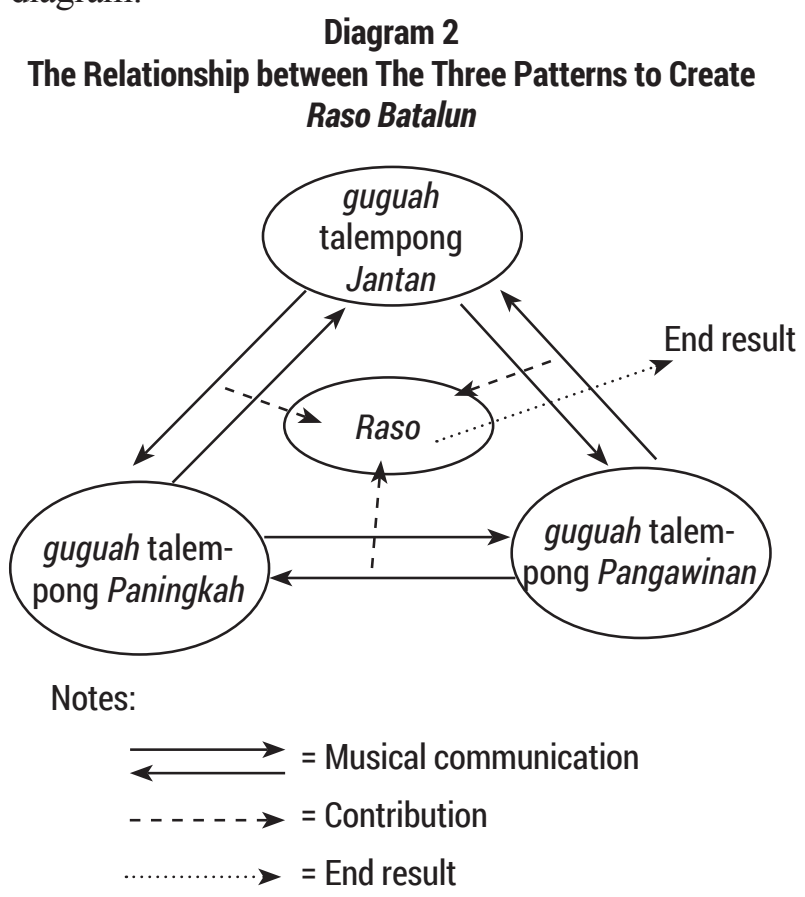

From the diagram above, we can see clearly that the musical interaction between the Guguah talempong Jantan and the Guguah talempong Paningkah shows a principle of dualism between two opposing poles-or bipolarity. The talempong Panyaua with a different Guguah also symbolizes the synthetic process that attempts to reach an aesthetical balance. The three rhythmic motifs synergize in the same position but with a different role to achieve an aesthetical quality known as raso batalun. In Yacob Sumardjo's opinion, this aesthetical principle of the Minangkabau people is founded on harmony. All things that are dualistic cannot be solved through victory or defeat on one side but rather the two must continue to exist as themselves-harmony is a paradox in peace (Yacob Sumardjo, 2010:267-268). This paradox in peace is a reflection of equality in difference. When the players are able to unite the different rhythms of the talempong Jantan, Paningkah, and Pangawinan, this will produce power, interest, and 
pleasure. All three have equality and difference in a unity to create raso batalun.

\section{External Communication}

External communication is a two-way communication which results from the musical communication that has been developed to become a single musical theme. In Santosa's opinion, musical communication is not a process without understanding-between the player and the audience-but rather a process which requires preparation, understanding, and contemplation that can be categorized as a creative action by both sides (Santosa, 2011:51). Communication with the audience leads to an expression of satisfaction when the communication touches the innermost feelings of the audience. In such a context, Santosa states that the process of communication that is taking place in the music has a broad impact on the way of thought, the sense of togetherness, and the aesthetical understanding (Santosa, 2011:42). To Boss, this is something which can give rise to pleasurable sensations (Budhisantoso, 1981/1982:24). When a pleasurable sensation appears, this means that the communication also stems from a pleasurable source.

\section{Galuik}

Galuik is an important part of creating raso batalun. It is essentially founded on musical communication, but the musical communication that takes place on the level of galuik places more emphasis on the technique of improvisation of rhythmic motifs performed by the talempong Panyaua player. The technique of improvisation will develop and emerge when playing talempong renjeang if the musicality and musical quality of the talempong Jantan, talempong Paningkah, and talempong Pangawinan players is of an equal musical ability and has the same level of sensitivity.

The understanding or communication among the three players is on an equal level in terms of their command of talempong performance so that they can complement one another. If they do not have the same level of musicality, the galuik talempong will fall below expectations. Traditionally, this kind of talempong performance is known as malacak batang. Malacak batang is a form of talempong performance that is still at an ordinary or beginners' level. There is no improvisation or surprise in the rhythmic motifs played on the talempong Pangawinan. Malacak batang is oriented more towards the musical ability of all the players in performing talempong together. On this level, they are aware that there is an interconnection or a relationship within the group that is needed in order to achieve a higher level of performance. This higher level is determined by their physical proximity to life, on the basis of a common desire, family ties, or the genealogical factors, as described above.

Malacak batang in the process of "becoming" requires a common perception and relation within a musical system in a particular group. Capra states that the existence of a person in his own world is bound to a conscious life network in a relational system-the need for mutual understanding. Mutual understanding is seen as the life system of an organism which is formed from a number of components that are arranged in the form of a network (Capra, 2002:123). Malacak batang in the process of "becoming" is bound to a network of musical communication with various components in order to reach a high level (mahia). Capra says that musical communication is a nonlinear relationship and a network of communication can produce a circle of feedbackthe concept of feedback being bound to the pattern of the network (Capra, 2002:124). Malacak batang becomes a concept which is built upon a network of reciprocal musical communication between the three talempong players in order to achieve the higher level (mahia).

In the process of "becoming", mahia combines skill with technical improvisation and feeling, or raso. Tingkek mahia is the ability to create a network of perception, skill, and raso for the guguah (rhythm) of the talempong when played in a professional way. This means that the 
talempong players work together within a musical network-including working together in the ability to use raso.

The ability to use raso properly is an integral part of talempong playing. It means that each player must have both an individual and collective ability to use raso. Individually, each player must be able to feel or sense the rhythmic patterns he plays. The use of raso in the command of rhythm aims to train the concentration of the players. Concentration is related to the area of demarcation-the boundary which prevents the player from going off track. Collectively, the use of raso guarantees that all three players will concentrate on remaining in their own musical area. This demands the appropriate use of raso and the ability to control it so as not to infringe on another person's area. In this way, each player is able to keep to the musicality of raso that is bound within a different rhythmic pattern. In order to concentrate, the talempong players always turn their faces away from one another so that they cannot see each other-unlike in the case of expression.

To Sumardjo, expression in art is the outpouring of a particular feeling in an atmosphere or mood of joy. This feeling is the response of an individual to something outside himself. It requires skill or technical ability in a particular medium (Sumardjo, 2000:74). Expression in a talempong performance is the implementation of the raso or sense of musicality of the player, based on the musical theme. The musical theme and the sense of musicality are always in a relational connection, in order to lead towards the achievement of an aesthetical quality. This raso or sense of musicality that is based on a theme appears rhythmically in the expression of the players when they give an attractive performance. The strength of the raso or sense of musicality can determine the raso in achieving an aesthetical quality-in batalun and malacak batang. This is also connected to the experience of musicality in various contexts and opportunities.

Musically speaking, galuik is the development of rhythmic motifs by the talempong Pangawinan
The role of the talempong Pangawinan is important in creating a musical raso which can lead to an impression of bagaluik (wrestling). This impression of bagaluik will appear when the talempong Pangawinan plays galuik that goes against the talempong Paningkah in the tempo that is played by the rhythms of the talempong Jantan. When this is done, the talempong players create the impression of bagaluik from the rhythms that they play. The musical expression developed by the three players in the various Guguah talempong is known as raso batalun.

It is quite conceivable that if the talempong players do not all come from the same group, there will be a problem with the musical communication between them. Musical communication is related to the command of musical techniques and musicality as part of the musical expression. Musical expression is oriented towards the achievement of an aesthetical feeling to create raso batalun. When the talempong players do not all come from the same group, it will be impossible for them to develop the galuik that can lead to raso batalun. This is because players from different groups will have different musical perceptions and different musical standards about the musical theme to be performed. If a player from a different group joins another talempong group, his presence and the role he plays may ruin the aesthetical atmosphere of the performance of talempong renjeang anam salabuhan.

\section{CONCLUSIONS}

The role of the group is an integral part of a talempong renjeang anam salabuhan performance. Internally, this role is closely related to the psychological burden and musical standard that the group must possess. A psychological burden will appear when a player has to join a different group with which he does not usually perform. Musical standard is the orientation for the aesthetical achievement of every talempong group. It is believed that this standard will never be reached if the role of a particular player is replaced by someone from outside the group. 
Talempong groups are divided into three categories; (1) groups that are formed through common interests and goals; (2) groups that are formed on the basis of family ties; and (3) groups that are based on genealogical connections. Groups that are founded on common interests and goals are well-organized while the other two categories-groups that are based on family ties and genealogical connections-are more traditional in nature. Aesthetically, the talempong performances by the last two kinds of groups have the ability to reach a musical standard which will allow them to achieve raso batalun.

A unity of raso is the basis upon good a performance will sound; a player who does not have the same perception or feeling as the other players in the group will disturb the musical feeling that has been developed in the group. A group has musical knowledge, a musical standard, and musical raso for the Guguah talempong of its own group. Raso batalun, as a form of aesthetics in a performance of talempong renjeang anam salabuhan, is essentially not a matter of beauty but rather of feeling, or raso, and a variety of different feelings will emerge from a Guguah talempong when it is played by a group of players who have equal abilities and the same musical sensibility.

The raso or sense of musicality of talempong players synergizes with the three different feelings of the players in the form of different rhythms which form a unit of musical raso. This unity of musical raso can be achieved through the harmony of the group. The unity of a group is determined by how the members are bound together by a common perception regarding the various different guguah talempong. This is oriented to the musical standard reached by each group in its performance of talempong renjeang anam salabuhan in order to achieve raso batalun. Raso batalun is the musical standard that every group wishes to achieve in the performance of talempong renjeang anam salabuhan in Luhak Nan Tigo Minangkabau. This musical standard is different for each talempong group, and it is this difference which determines that the group concept is the representation of the social concept of each group.

\section{REFERENCES}

Adam, Boestanuel Arifin. (1986/1987). "Talempong Musik Tradisional Minangkabau". Research Report. ASKI Padangpanjang.

Budisantoso, S. (1981/1982). "Kesenian dan Nilai-Nilai Budaya." in Analisis Kebudayaan. Year II. No. 2, 24.

Capra, Fritjof. (2002). Jaring-Jaring Kehidupan Visi Baru Epistimologi dan Kehidupan. Translation by Saut Pasaribu. Yogyakarta: Fajar Pustaka Baru.

Dharsono. (2011). Estetika. Bandung: Rekayasa Sains.

Deleuze, Gilles \& Felix Guattari. (2010). What Is Philosophy: Reinterpretasi atas Filsafat, Sain dan Seni. Translation by Muh. Indra Purnama. Yogyakarta: Jalasuta.

Fiske, John, (2011). Memahami Budaya Populer. Translation by Asma Bey Mahyudin. Yogyakarta: Jalasutra.

Giddens, Anthony. (2011). The Constitution of Society: Teori Strukturasi untuk Analisis Sosial. Terjemahan Adi Loka Sujono. Yogyakarta: Penerbit Pedati.

Hardjana, Suka. (1983). Estetika Musik. Jakarta: Department of Education and Culture.

Hastanto, Sri. (2012). Ngeng \& Reng: Persandingan Sistem Pelarasan Gamelan Ageng Jawa dan Gong Kebyar Bali. Surakarta: ISI Press.

Kak Seto, http://www. psikomedia.com/article/vliew/ Psikologi/2136/Si-Kembar-Berkomuni-kasiLewat-Telepati/.

Sairin, Sjafri. (1995). Demokrasi dalam Kebudayaan Minangkabau. Jurnal Humaniora, 87-93.

Santosa. (2011). Komunikasi Seni Aplikasi dalam Pertunjukan Gamelan. Surakarta: ISI Press.

Sedyawati, Edi. (2007). Budaya Indonesia Kajian Arkeologi, Seni, dan Sejarah. Jakarta: Raja Grafindo Persada.

Sugono, Dendy. (2008). Kamus Bahasa Indonesia. Jakarta: Language Centre, Department of National Education.

Sumardjo, Yakob. (2000). Filsafat Seni. Bandung: Penerbit ITB.

Sutiyono. (2011). Fenomenologi Seni: Meneropong Fenomena Sosial dalam Kesenian I. Yogyakarta: Insan Persada. 